Jurnal Penelitian dan Pengabdian Kepada Masyarakat Bidang ilmu Pendidikan

\title{
Kesulitan Guru Dalam Menerapkan Teknik Pembelajaran Number Head Together (NHT) di Sekolah Dasar
}

\author{
Mulya Yusnarti \\ Dosen Program Studi Pendidikan Guru Sekolah Dasar, STKIP Yapis Dompu \\ E-mail:mulyayusnarti@gmail.com
}

Article History: Received: 2020-09-14 || Revised: 2020-10-02 || Published: 2020-10-26

Sejarah Artikel : Diterima: 2020-09-14 || Direvisi: 2020-10-02 || Dipublikasi: 2020-10-26

\begin{abstract}
The Based on the results of data analysis that the learning process by using the Numbered Head Together (NHT) model applied by teachers in SD Negeri 25 Dompu in the 2018/2019 academic year is in the introduction of the active teacher in dividing groups, then the teacher asks questions to students. The teacher encourages students to work together to exchange ideas, in the stages of responding to questions the teacher encourages students to be active in answering questions to find out students' understanding of the material being taught. In teacher and student activities, the teacher can arouse students' interest and motivation to learn. When the discussion process takes place the teacher can direct students to discuss. Whereas in the closing activity the teacher actively facilitates each group to conclude the learning material.
\end{abstract}

Keywords: Difficulties, Cooperative Learning, NHT Learning

\begin{abstract}
Abstrak
Berdasarkan hasil analisis data bahwa proses pembelajaran dengan penggunaan model Numbered HeadTogether (NHT) yang diterapkan oleh guru di SD Negeri 25 Dompu tahun pembelajaran 2018/2019 yaitu pada bagian pendahuluan guru aktif dalam membagi kelompok, selanjutnya guru mengajukan pertanyaan kepada siswa. Guru menganjurkan kepada siswa untuk bekerja sama saling tukar pikiran, dalam tahapan menanggapi pertanyaan guru menganjurkan kepada siswa untuk aktif dalam menjawab pertanyaan untuk mengetahui pemahan siswa terhadap materi yang telah di ajarkan. Pada aktivitas guru dan siswa, guru dapat membangkitkan minat dan motivasi belajar siswa. Saat proses diskusi berlangsung guru dapat mengarahkan siswa untuk berdiskusi. Sedangkan pada kegiatan penutup guru aktif menfasilitasi setiap kelompok dalam menyimpulkan materi pembelajaran.
\end{abstract}

Kata kunci: Kesulitan, Pembelajaran Kooperatif, Pembelajaran NHT

\section{PENDAHULUAN}

Pendidikan merupakan suatu kebutuhan yang bersifat mendasar dan harus dipenuhi oleh setiap siswa yang memiliki pengetahuan luas dalam kehidupannya. Pendidikan ini dapat diperoleh hanya dengan proses belajar, baik lembaga pendidikan formal maupun informal. Belajar merupakan suatu kegiatan yang bertujuan untuk mengubah tingkah laku seseorang kearah yang lebih baik. Pendidikan utama yang di tempuh oleh seseorang kearah yang lebih baik. Pendidikan pertama yang ditempuh oleh seseorangsebelummenempuh dari kedua pendidikan di atas adalah pendidikan keluarga. Beberapa faktor yang mempengaruhi dalam keberhasilan dari kegiatan pembelajaran salah satu diantaranya adalah metode pembelajaran. Pemilihan dan penggunaan metode pembelajaran yang tepat diharapkan dapat membantu siswa lebih mudah menerima dan memahami materi sehingga dapat berpengaruh terhadap prestasi belajar siswa Ketepatan dalam penggunaan metode pembelajaran yangdilakukan oleh guru akanmembangkitkan aktivitas dan minat terhadap mata pelajaran yang diberikan, dalam kegiatan pembelajaran dan pencapaian 
prestasi belajar siswa. Keberhasilan suatu proses pendidikan dapat dilihat dari tinggi rendahnya prestasi siswa yang dapat diukur dari segi afektif, kognitif dan psikomotornya.

Menurut Isjoni, (2011: 81) Pembelajaran kooperatif merupakan strategi alternatif untuk mencapai tujuan meningkatkan kemampuan siswa dalam bekerja sama, berpikir kritis yang dapat meningkatkan prestasi akademik, membantu siswa memahami konsep-konsep pelajaran IPS yang sulit dan sangat berguna untuk menumbuhkan kemauan kerja sama dan kemauan membantu teman. Menurut Hamdani (2011: 30) Salah satu ciri pembelajaran kooperatif adalah kemampuan siswa untuk bekerja sama dalam kelompok kecil yang heterogen. Masing-masing anggota dalam kelompok memiliki tugas yang setara. Karena pada pembelajaran kooperatif keberhasilan kelompok sangat diperhatikan, maka siswa yang pandai ikut bertanggung jawab membantu temannya yang lemah dalam suatu kelompoknya.Sedangkan peran guru lebih ditekankan sebagai organisator kegiatan belajar mengajar, sumber informasi bagi siswa, pendorong bagi siswa untuk belajar, serta penyedia materi dan kesempatan belajar bagi siswa. Guru harus dapat mendiagnosis kesulitan siswa dalam belajar dan dapat memberikan bantuan kepadanya sesuai dengan kebutuhannya.

Menurut Isjoni, (2011:81) Model pembelajaran NumberedHead Together (NHT) termasuk dalam pembelajaran kooperatif. Pembelajaran ini dimulai dengan membagi siswa dalam beberapa kelompok, langkah selanjutnya penomoran (numbering) kepada parasiswa tiap kelompok, pengajuan pertanyaan (Questioning) yang dilakukanguru kepada siswa, berpikir bersama (Heads Together) yaitu siswa menyatukan ide untuk menemukan jawabannya, dan pemberian jawaban (Answering) yaitusiswa dari masing-masing kelompok yang memiliki nomor tersebut mengangkat tangannya dan memberikan jawabannya di hadapan seluruh kelas. Agar membantu meningkatkan prestasi belajar siswa perlu kerjasama berbagai pihak diantaranya guru, orang tua dan siswa selain itu teknik yang digunakan oleh guru dalam proses pembelajaran menjadi hal penting seperti teknik Numbered Head Together (NHT). Menurut Nasution (2000: 34) "Cara atau teknik dalam menyajikan pelajaran sangat mempengaruhi jalannya proses pembelajaran di sekolah. Sebab hakekat dari cara atau metode pembelajaran itu adalah upaya yang dilakukan untuk mengefektifkan pencapaian dan tujuan pembelajaran serta metode yang digunakan itu harus sesuai dengan bahan atau materi yang disampaikan".

Berdasarkan hasil observasi awal yang dilakukan peneliti pada tanggal 2 Februari dan 2 Maret 2018 pukul 09.00 Wita di SD Negeri 25 Dompu ternyata guru pernah menggunakan teknik NHT namun pada saat kegiatan pembelajaran justru siswa kurang antusias, beberapa siswa yang terlihat aktif baik mendengarkan materi, memperhatikan, maupun mencatat penjelasan yang diberikan oleh guru tentang kenampakan alam di Indonesia guru mengalami kesulitan dalam menerapkan teknik pembelajaran NHT yang diantaranya guru sulit memahami tahapan-tahapan teknik pembelajaran Numbered Head Together (NHT) untuk itu perlu adanya metode pembelajaran yang menyenangkan sehingga siswa dapat berperan aktif dalam proses pembelajaran yang dapat meningkatkan prestasi belajar dan menitik beratkan pada keaktifan siswa dan memerlukan kemampuan interaksi sosial yang baik antara semua komponen pengajaran, sehingga memudahkan siswa menguasai, memahami materi untuk mencapai tujuan bersama.

Berdasarkan permasalahan di atas sehingga peneliti ingin mengadakan penelitian lebih lanjut dengan mengangkat judul: Kesulitan guru dalam menerapkan teknik pembelajaran number heads together (NHT) di SD Negeri No. 25 Dompu tahun pembelajaran 2018/2019. 


\section{METODE PENELITIAN}

Jenis penelitian ini adalah penelitian etnografi dengan pendekatan kualitatif karena data yang dicari dalam penelitian ini, membutuhkan penelitian langsung di lapangan. Oleh karena itu jenis penelitiankualitatifsangat sesuai atau relevan dengan penelitian ini. Alasan penggunaan penelitian kualitatif karena peneliti akan melakukan penelitian secara langsung di sekolah untuk mengetahui faktor tentang kesulitan guru dalam menerapkan metode pembelajaran NHT. Disamping itu peneliti harus berinteraksi langsung dengan sember data dan mengenal betul orang yang memberikan data. Menurut Arikunto (2010:21) penelitian daksriptif merupakan penelitian yang dimaksud untuk mengumpulkan informasi mengenai gejala yang ada menurut kenyataan pada saat penelitian dilakukan, dan tidak memerlukan administrasi dan pengontrolan terhadap suatu perlakuan.Bogda dan Taylor (dalam Meleong, 2001: 4) mendefinisikan "bahwa penelitian kualitatif sebagai prosedur penelitian yang menghasilkan data deksriptif berupa kata-kata tertulis atau lisan dari orang-orang dan prilaku yang dapat di amati”. Sejalan dengan definisi tersebutKirk dan Miller (dalam Moleong, 2001: 5) Menjelaskan "bahwa penelitian kualitatif adalah tradisi tertentu dalam ilmu pengetahuan sosial yang secara fundamental bergantung pada pengamatan pada manusia dalam kawasannya sendiri dan berhubungan dengan orang-orang tersebut dalam bahasanya dan dalam peristilahanya".

Penelitian ini di laksanakan di SDN 25 Dompu, dengan alasan bahwa di SD Negeri 25 Dompu merupakan sekolah uggulan yang membutuhkan pengembangan dalam kegiatan pembelajaran. Sumber data yang digunakan adalah sumber informasiyang berkaitan dengan data yang akan di butuhkan sebagai pendukung perihal yang ingin di ketahui. Superi (dalam Moleong, 2001: 16), menjelaskan bahwa "sumber data terdiri atas dua jenis yaitu sumber data primer dan sumber data sekunder". Data primer disebut juga sebagai data asli. Untuk mendapatkan data primer, peneliti harus mengumpulkannya secara langsung. Teknik yang dapat digunakan peneliti untuk mengumpulkan data antara lain observasi, diskusi dan wawancara. Adapun yang menjadi sumber data primer ialah data dalam bentuk verbal atau kata-kata yang diucapkan secara lisan yang dapat dipercaya dari sumber data Guru mata pelajaran IPS yang berinisial (NR) serta tiga orang siswa kelas IV di SD Negeri 25 Dompu.

Data sekunder adalah data pendukung untuk melengkapi data yang telah diperoleh dari sumber primer. Dalam penelitian ini sumber data sekunder adalah hasil observasi dan dokumentasi, adapun jenis data yang di gunakan yang di dapatkan dari guru wali kelas berupa daftar nama siswa, silabus, RPP, nilai dan prestasi belajar masing-masing informan. Selain dari itu terdapat dokumentasi untuk melengkapi penelitian ini dapat diperoleh dari buku, artikel dan jurnal. Dari uraian di atas dapat disimpulkan bahwa sumber data sekunder dalam penelitian ini adalah kepala sekolah dan juga berasal dari buku-buku yang ada dan masalah yang diteliti kemudian untuk dijadikan referensi serta data sekunder yang bersal dari hasil observasi terhadap kesulitan guru dalam menerapkan teknik pembelajaran NHT pada matapelajaran IPS SD Negeri 25 Dompu tahun pembelajaran 2018/2019.

Ada tiga teknik pengumpulan data yang digunakan dalam penelitian ini yaitu: 1) Observasi, 2) Wawancara, dan 3) Dokumentasi. Observasi dilaksanakan pada tanggal 14-15 september 2018, observasi akan dilaksanakan di SD Negeri 25 Dompu untuk memperoleh atau mendapatkan data tentang kesulitan guru dalam menerapkan teknik pembelajaran NHT dengan menggunakan instrumen lembar pengamatan aktivitas guru dan siswa. Selanjutnya Menurut Corbin, (dalam Sugyono, 2015: 137) "bahwa wawancara adalah proses tanya jawab lisan antara dua orang atau lebih secara langsung". Pewawancara disebut sebagai interviewer dan orang yang diwawancarai disebut sebagai interviewe.Wawancara bertujuan untuk mendapatkan data dari tangan pertama 
(primer), sebagai pelengkap teknik pengumpulan lainya,dan untuk menguji hasil pengumpulan data lainya. Sedangkan dokumentasi adalah suatu cara yang dilakukan untuk menyediakan dokumen dengan menggunakan bukti yang akurat dari pencatatan sumber informasi khusus dari sebuah karangan atau tulisan, wasiat, buku, undang-undang dan lainnya.

Tehnik analisis data yang dilakukan yaitu, dengan menggunakan analisis kualitatif. Analisis dilakukan selama dan setelah pengumpulan data. Menurut Meleong (2001:288-289), mengungkapkan proses analisis data dalam penelitian akan dilakukan dengan cara-cara sebagai berikut: Proses reduksi data yaitu, memilih atau menyeleksi data yang sudah terkumpulkan lalu memasukan kedalam tema, kategori, fokus, atau permasalahan penelitian, selanjutnya Proses display data yaitu penyajian data dilakukan dalam bentuk uraian singkat, dan teks yang bersifat naratif. Dengan kata lain proses ini adalah proses pengurutan data sesuai dengan waktu kejadian dan hal-hal yang memiliki keterkaitan untuk mendapatkan suatu interprestasi terhadap data penelitian. Dalam proses display data dilapangan akan dipilih dan mengurut data-data yang diambil di sekolah seperti data guru dan siswa, dan penulisan yaitu data yang terkumpul dengan pelukisan atau penurutan tentang masalah-masalah yang dibahas dalam penelitian ini baik masalah, kapan,dimana serta halyang melatarbelakangikesulitan yang dialami oleh guru dalam menerapkan teknik pembelajaran NHT di SD Negeri 25 Dompu, seperti halnya pembentukan kelompok, mengajukan pertanyaan dan mengevaluasi.

Setelah sumber-sumber dikumpulkan maka kegiatan selanjutnya adalah verifikasi atau lazim disebut juga dengan kritik sumber dalam memperoleh keabsahan sumber. Tujuan kritik seluruhnya ialah menyeleksi data menjadi fakta. Karna umumnya biasa data dan fakta dicampur adukkan. Data ialah semua bahan, sedangkan fakta adalah semua bahan diujikan dengan kritik, jadi fakta itu sudah terkoreksi. Meleong, (2001: 280) menyebutkan bahwa dalam penelitian diperlukan dalam suatu tehnik pemeriksaan keabsahan data. Sedangkan untuk memperoleh keabsahan temuan perlu diteliti kredibilitasnya dengan menggunakan tehnik presisten observation, triangulasi, teknik triangulasi.

\section{HASIL DAN PEMBAHASAN}

\section{A. Paparan Data}

\section{Deskripsi Hasil Wawancara}

Dalam deskripsi hasil penelitian ini akan diuraikan tentang hasil penelitian berdasarkan hasil wawancara peneliti dengan nara sumber. Berdasarkanhasil wawancara, dilapangan tentang kesulitan guru dalam menerapkan teknik pembelajaran Number Heads Together (NHT) di SDNegeri25 Dompu tahun pembelajaran 2018/2019.

\section{a) Hasil wawancara dengan guru}

Tabel 1 Hasil Wawancara dengan Guru

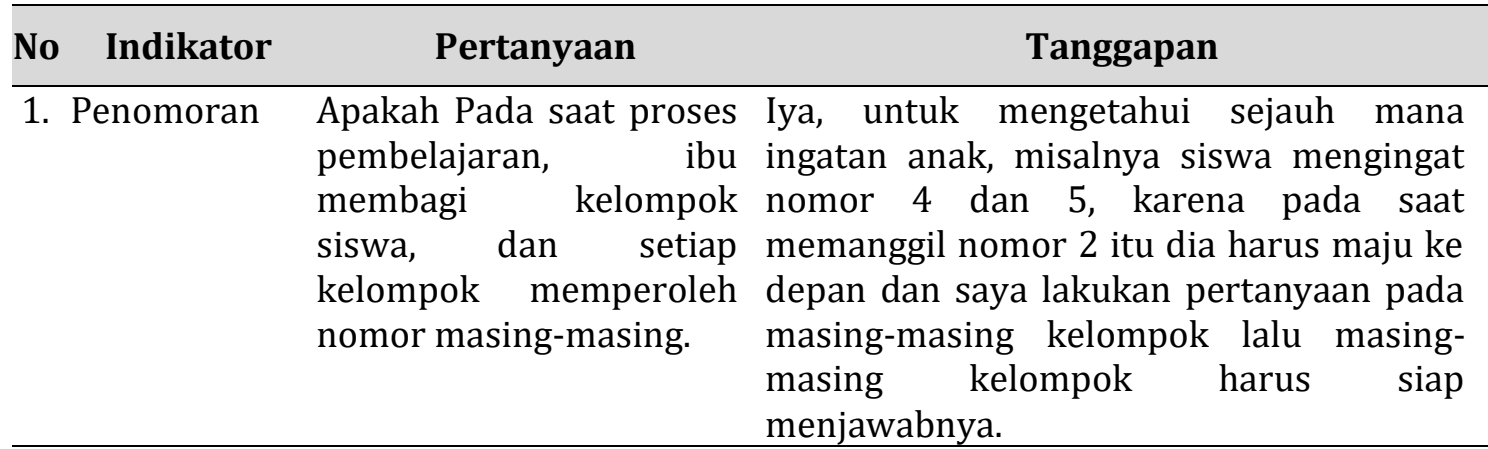

2. Mengajukan Apakah ibu mengajukan Iya, saya mengajukan pertanyaan kembali Pertanyaan pertanyaan pada masing- terhadap materi yang saya ajarkan untuk 
masing kelompok mengetahui sejauh mana anak itu tentang materi mengetahui materi yang diajarkan. Entah pembelajaran IPS. lewat membaca buku dari awal atau pengetahuan-pengetahuan lain yang dia dengar lewat televisi atau radio, maupun tanya jawab dengan teman-temannya.

3. Berfikir Apakah ibu menyarankan Iya, saya menyuruh siswa kerja kelompok, bersama masing-masing kelompok karena salah satu siswa itu berbeda untuk mendiskusikan pendapatnya, untuk bisa menyatukan materi tentang berbagai macam jawaban sesuai dengan kenampakan alam di LKS yang dibagikan dan untuk indonesia sesuai dengan mendapatkan pengetahuan-pengetahuan LKS yang dibagikan. yang lain. Sehingga jawabanya bisa mencapai maksimal

4. Menjawab

Apakah ibu memberikan Iya, karena untuk mengetahui sejauh mana kesempatan kepada pemahaman mereka dari hasil yang di masing-masing kelompok diskusikan tentang materi yang di ajarkan. untuk mempresentasikan Dan siswa di tumbuhkan rasa keberanian hasil diskusi. untuk mempresentasikan hasil diskusinya didepan dan agar siswa bisa bertanggung jawab terhadap apa yang di buatnya.

Berdasarkan hasil wawancara dengan guru kelas IV SD Negeri 25 Dompu tentang kesulitan guru dalam menerapkan teknik pembelajaran Number Heads Together (NHT) dapat ditarik kesimpulannya bahwa dalam proses belajar mengajar guru mengalami kesulitan dalam mengatur dan membagikan kelompok kepada siswa, karena siswa lebih cenderung memilih teman dekat untuk menjadi anggota kelompok. Selain itu dalam proses diskusi siswa sulit bekerja sama dengan anggota kelompok. Pada tahap menjawab pertanyaan yang telah di ajukan oleh guru, siswa mengalami kesulitan untuk memaparkan hasil pekerjaannya karena perasaan takut.

\section{b) Hasil wawancara dengan siswa}

Adapun hasil wawancara dengan siswa dalam kegiatan penelitian ini, yakni: Tanggapan siswa tentang penggunaan media pembelajaranNumber Heads Together (NHT). Penggunaan media pembelajaran NHT dapat memberikan semangat kepada siswa untuk mengikuti pelajaran.Siswa merasa senang dengan kegiatan pembelajaran NHT. (wawancara dengan Angga Prayoga siswa kelas IV, di wawancarai pada pukul 10.00 Wita hari selasa 4 September 2018).

Keaktifan siswa pada saat proses pembelajaran di kelas berlangsung sebagian siswa aktif dalam mengikuti pembelajaran dengan teknik NHT. Namun masih ada siswa yang kurang aktif dan merasa bosan dengan penggunaan media NHT tersebut seperti bermain sendiri dan tidak mengikuti kegiatan pembelajaran secara maksimal. (wawancara dengan Alisa Putri siswa kelas IV, di wawancarai pada pukul 10.00 Wita hari selasa 4 September 2018). Kerja sama. Teknik pembelajaran NHT membantu siswa dalam menumbuhkan kerja sama antara anggota kelompok, siswa saling tukar pikiran untuk menyelesaikan soal-soal yang telah dibagikan oleh guru. Disisi lain masih ada siswa yang tidak mau bekerja sama dengan teman-temannya dan tidak menerima pendapat temannya. (wawancara dengan Evi siswa kelas IV, di wawancarai pada pukul 10.00 Wita hari selasa 4 September 2018). 
Tanggung jawab.Dengan penggunaan media pembelajaran Number Heads Together (NHT) siswa diberi tanggung jawab secara pribadi dan kelompok untuk menyelesaikan soal-soal yang telah diberikan oleh guru.Dengan media tersebut siswa dilatih untuk menumbuhkan rasa tanggung jawab, namun kenyataannya masih banyak yang tidak menyelesaikan tugas dan hanya bergantung pada teman dalam kelompok. (wawancara dengan Rahman siswa kelas IV, di wawancarai pada pukul 10.00 Wita hari selasa 4 September 2018).

Kepercayaan diri.Dengan penggunaan media pembelajaran NHT siswa diberikan kepercayaan untuk mempresentasikan hasil pekerjaannya masing-masing dengan tujuan siswa dilatih untuk memiliki keberanian dan menumbuhkan rasa kepercayaan diri kepada siswa.pada saat mempresentasikan hasil diskusi masih banyak siswa yang tidak berani maju kedepan. (wawancara dengan Riski siswa kelas IV, di wawancarai pada pukul 10.00 Wita hari selasa 4 September 2018).

Berdasarkan hasil wawancara dengan siswa diatas tentang penggunaan media pembelajaran NHT dapat ditarik kesimpulanya yaitu dalam proses pembelajaran siswa merasa nyaman dan senang mengikuti pembelajaran dengan teknik NHT, siswa aktif dalam mengikuti pembelajaran namun masih ada sebagian siswa yang tidak fokus yang bermain sendiri. Pembelajaran NHT dapat menumbukan saling kerja sama antara anggota kelompok dan saling tukar pikiran. Selain itu dengan pembelajaran NHT siswa dapat bertanggung jawab terhadap diri sendiri dan kelompok dalam menyelesaikan soal dari guru.Dengan pembelajaran NHT siswa dilatih untuk berani tampil untuk mempresentasikan tugas serta menumbuhkan sikap kepercayaan diri kepada siswa.

\section{Deskripsi Hasil Observasi}

Berikut ini akan dijabarkan terkait dengan deskripsi hasil observasi, sebagai berikut:

\section{a) Hasil Observasi Aktivitas Guru}

Kegiatan pembelajaran dengan media NHT pada tahap pendahuluan guru mengalami kesulitan dalam membangkitkan minat dan motivasi belajar siswa sehingga siswa sulit di arahkan untuk fokus dalam memahami materi pembelajaran.Selain itu guru tidak menyampaikan tujuan pembelajaran kepada siswa sehingga siswa tidak termotivasi untuk mengikuti kegiatan pembelajaran.

Pada saat kegiatan pembelajaran berlangsung guru mengalami kesulitan dalam mengarahkan siswa untuk berdiskusi, siswa cenderung tidak fokus untuk berdiskusi.Selain itu guru tidak memberikan kesempatan secara menyeluru untuk siswa dalam mempresentasikan hasil diskusi sehingga siswa tidak fokus untuk benar-benar mendalami materi pembelajaran.

Dalam proses pembelajaran media NHT, pada kegiatan penutup guru tidak menfasiltasi kelompok siswa dalam menyimpulkan materi pembelajaran, serta guru tidak melakukan evaluasi kepada siswa baik berupa tugas sekolah maupun pekerjaan rumah (PR). (Observasi ibu Nur Nahningsih, S.Pd. guru kelas IV, di observasi pada pukul 09.00 Wita hari rabu 5 September 2018).

\section{b) Hasil Observasi Aktivitas Siswa}

Berdasarkan hasil observasi aktivitas siswa dalam penerapan teknik pembelajaran NHT dari 5 kelompok yang dibentuk masih ada 2 kelompok yang kurang aktif yaitu kelompok II dan kelompok V. Siswa kurang memperhatikan materi yang disampaikan oleh 
guru, selin itu siswa kurang aktif dalam menanggapi pertanyaan-pertanyaan yang diberikan oleh guru. Pada saat proses diskusi kelompok siswa kurang bekerja sama dengan anggota kelompok masing-masing. Dan pada saat mempersentasikan hasil diskusi siswa tidak berani untuk maju didepan. (Observasi dengan siswa kelas IV. Di obesrvasi pada pukul 09.00 wita, hari rabu 5 september 2018).

Berdasarkan hasil observasi tentang aktivitas guru dan siswa dalam penerapan teknik pembelajaran Number Heads Together (NHT) pada aktivitas guru, tahap pendahuluan guru mengalami kesulitan dalam membangkitkan motivasi belajar siswa, selain itu guru tidak menyampaikan tujuan dari pembelajaran dengan menggunakan teknik NHT. Pada tahap kegiatan inti guru mengalami kesulitan dalam mengontrol jalannya kegiatan diskusi pada masing-masing kelompok serta guru tidak memberikan kesempatan pada siswa secara merata untuk mempresentasikan hasil diskusi. Pada kegiatan penutup guru tidak menfasilitasi siswa dalam tiap kelompok diskusi untuk membantu menyimpulkan materi pembelajaran.

Sedangkan aktivitas siswa dalam penerapan teknik pembelajaran NHT terdapat 2 kelompok yang kurang aktif yaitu kelompok II dan kelompok V. Dari kegiatan pembelajaran kedua kelompok tersebut menunjukan aktivitas Siswa kurang memperhatikan materi yang disampaikan oleh guru, siswa kurang aktif dalam menanggapi pertanyaan-pertanyaan yang diberikan oleh guru, saat proses diskusi siswa kurang bekerja sama dengan anggota kelompok masing-masing. Dan pada saat memperesentasikan hasil diskusi siswa tidak berani untuk maju didepan.

\section{B. Pembahasan}

Banyak faktor-faktor yang mempengaruhi keberhasilan kegiatan pembelajaran salah satu diantaranya adalah penerapan teknik pembelajaran. Pemilihan dan teknik pembelajaran yang tepat diharapkan dapat membantu siswa untuk menerima dan memahami materi pembelajaran sehingga siswa memiliki motivasi yang besar dalam mengikuti proses pembelajaran. Keberhasilan suatu proses pembelajaran dapat dilihat dan diukur dari segi afektif, kognitif dan psikomotornya. Menurut Isjoni, (2011: 81) Pembelajaran kooperatif merupakan strategi alternatif untuk mencapai tujuan meningkatkan kemampuan siswa dalam bekerja sama, berpikir kritis yang dapat meningkatkan prestasi akademik, membantu siswa memahami konsep-konsep pembelajaran IPS. Sedangkan teknik pembelajaran NHT menurut Kagen (dalam Khaeruman, 2014: 123) merupakan pendekatan untuk melibatkan banyak siswa dalam memperoleh materi yang tercakup dalam suatu pembelajaran dan mengecek pemahaman mereka terhadap isi pembelajaran.

Berdasarkan hasil penelitian bahwa proses pembelajaran dengan penggunaan media Numbered Head Together (NHT) di SD Negeri 25 Dompu tahun pembelajaran 2018/2019 yaitu guru mengalami kesulitandalam hal mengatur dan membagikan kelompok kepada siswa, dikarenakan siswa lebih cenderung memilih teman dekat untuk menjadi anggota kelompok. Selanjutnya guru mengalami kesulitan dalam mengontrol jalannya diskusi pada tiap-tiap kelompok dan guru tidak memberikan kesempatan kepadai siswa dalam tiap kelompok untuk menyimpulkan materi pembelajaran. Selain itu dengan kurangnya kemampuan guru dalam menerapkan teknik pembelajaran NHT, sehingga siswa kurang memperhatikan materi yang disampaikan oleh guru, siswa kurang aktif dalam menanggapi pertanyaan-pertanyaan yang diberikan oleh guru, saat proses diskusi siswa kurang bekerja sama dengan anggota kelompok lainya. Dan pada saat memperesentasikan hasil diskusi siswa tidak berani untuk maju didepan. 
Berdasarkan uraian hasil penelitiandi atas bertolak belakang dengan tujuan pembelejaran NHT adalah dapat merangsang siswa untuk selalu siap kapan saja ketika dipanggil nomornya dalam kelompok sehingga menuntut mereka untuk berinteraksi dan memecahkan masalah bersama-sama dengan cepat dan tepat. Hal tersebut didukung dengan pendapat Ibrahim (2009: 60) mengatakan bahwa "teknik pembelajaran kooperatif tipe NHT merupakan pembelajaran yang dilaksanakan secara kelompok, sehingga siswa diberikan kesempatan untuk saling membagikan ide-ide dan mempertimbangkan jawaban yang paling tepat untuk menyelesaikan proses pembelajaran.

\section{SIMPULAN DAN SARAN}

\section{A. Simpulan}

Berdasarkan temuan dalam penelitian dan pembahasan mengenai kesulitan guru dalam menerapkan teknik pembelajaran NHT pada matapelajaran IPS siswa SD Negeri 25 Dompu, dapat disimpulkan bahwa guru sudah maksimal dalam menerapkan media pembelajaran teknik NHT dalam setiap proses pembelajaran, walaupun masih ada di sebagian tahapan pembelajaran NHT masih kurang. Hal ini dapat dilihat pada tahap persiapan pembelajaran berlangsung guru membagikan kelompok kepada siswa untuk berdiskusi tentang kenampakan alam Indonesia. Pada saat proses pembelajaran berlangsung guru memberikan waktu kepada kelompok untuk mempresentasikan hasil pekerjaannya, serta mengajukan pertanyaan. Sehingga siswa antusias untuk melatih keberanian dengan tampil mempresentasikan tugas tersebut. Sedangkan pada saat proses pembelajaran teknik NHT siswa mengalami kesulitan pada tahap diskusi dan persentase masih ada sebagian siswa yang tidak berani tampil didepan untuk mempresentasikan hasil diskusi. Dari hasil observasi dan wawancara dari semua indikator dalam penelitian ini, disimpulkan dapat menunjang bahwa guru dalam memaksimalkan penerapan teknik pembelajaran NHT sehingga siswa aktif untuk mengikuti kegiatan pembelajaran.

\section{B. Saran}

Sehubungan dengan hasil penelitian ini maka penulis menyarankan:

1. Kepada kepala sekolah agar selalu memberikan dukungan terhadap guru untuk menerapkan media pembelajaran yang sesui dengan kemampuan siswa, khususnya pada pembelajaran IPS.

2. Kepada pihak guru untuk memilih dan mengembangkan media pembelajaran NHT dalam setiap proses kegiatan pembelajaran yang berlangsung sesuai dengan kebutuhan materi guna memberikan pemahaman yang kongkrit kepada siswa.

3. Kepada peneliti lain untuk bisa mengkaji dan meneliti ulang masalah ini, sebab hasil penelitian ini masih jauh dari kesempurnaan. Hal ini dikarenakan keterbatasan pengetahuan yang dimiliki oleh peneliti, namun demikian semoga hasil penelitian ini bisa dijadikan acuan untuk penelitian selanjutnya.

\section{DAFTAR RUJUKAN}

Arikunto, S. 2010. Prosedur Penelitian Suatu Pendekatan Praktik. Jakarta: Rineka Cipta

Arikunto, S. 2006. Prosedur Penelitian Suatu Pendekatan Praktik. Jakarta: Rineka Cipta

Azizah Oktafiana. 2009. Model-pembelajaran-nht-nht-numbered-head together/ (Online) https://herdy07.wordpress.com/2009/04/22/modelpembelajaran-nht-numbered-headtogether/di akses 10 april 2018.

Balitbang Depdiknas. 2002. Pelaksanaan kurikulum berbasis kompetensi. Jakarta: Departemen Pendidikan Nasional. 
Binti Maunah. 2009. Landasan pendidikan. Yogyakarta: Teras.

Depdiknas. 2013. Peraturan Mentri Pendidikan dan Kebudayaan RI No. 65, tahun 2013, tentang Standar Proses Pendidikan Dasar dan Menengah. Jakarta: Depdiknas.

Dim Yati Mujono. 2009. Belajar dan pembelajaran.Jakarta: PT. Rineka Cipta.

Hamalik, Oemar. 2009. Proses Belajar Mengajar. Bandung : Bumi Aksara.

Hamdani, 2011. Startegi Belajar Mengajar. Bandung: Pustaka Setia.

Ibrahim. 2009. Pembelajaran Kooperatif. Surabaya: UNESA-UNIVERSITY PRESS kampus UNESA.

Isjoni. 2011. Cooperative Learning Efektivitas Pembelajaran Kelompok. Bandung: Alfabeta

Khaeruman, 2014. Trik-trik mengajar. Mataram.

Moleong. L. J. 2001. Metode Penelitian Kuantitatif. Bandung. PT. Remaja Rosda karya.

Nasution. 2000. Didaktik Asas-Asas Megajar. Jakarta: Bumi Aksara.

Sugiyono.2015. Metode Penelitian Kuantitatif, kualitatif dan $R \& D$, Bandung: Alfabeta

Slavin, Robert E., 2005.Cooperatif Learning: Theory, Recearch, and Practice. Bandung: Nusa Media

Suwarno. (2010). Pembelajaran Kooperatif Jenis Numbered Heads Together, diakses melalui http://suwarnostatistik.wordpress.com.

Suprijono. 2009. Cooperative Learning Teori dan Aplikasi Paikem: Yogyakarta: Pustaka Pelajar.

Taniredja, Tukiran, dkk. 2010. Penelitian Tindakan Kelasuntuk Pengembangan Profesi Guru. Bandung: Alfabeta. 